\title{
Applications of Capillary Electrophoresis to the Analysis of Compounds of Clinical, Forensic, Cosmetological, Environmental, Nutritional and Pharmaceutical Importance
}

\author{
Marina F. M. Tavares*, Alessandra V. Jager, Clóvis L. da Silva, Edgar P. Moraes, \\ Elisabete A. Pereira, Elizabete C. de Lima, Fabiana N. Fonseca, Fernando G. Tonin, \\ Gustavo A. Micke, Márcia R. Santos, Marcone A. L. de Oliveira, Maria de Lourdes L. \\ de Moraes, Maria Helena van Kampen and Neide M. Fujiya \\ Instituto de Química, Universidade de São Paulo, CP 26077, 05513-970 São Paulo - SP, Brazil
}

\begin{abstract}
Desde sua implementação na década de 80, a eletroforese capilar vem evoluindo, tornando-se uma técnica de separação bem estabelecida e, hoje, engloba de fato, uma família de técnicas eletrocinéticas, com mecanismos de separação distintos e seletividade característica, todas passíveis de serem conduzidas em uma única coluna capilar. Neste trabalho, a versatilidade da eletroforese capilar para lidar com materiais de diferentes classes químicas e matrizes complexas é ilustrada, apresentando aplicações representativas nas áreas clínica, forense, cosmética, ambiental, nutricional e farmacêutica, compilando os interesses de pesquisa e resultados do nosso próprio grupo.
\end{abstract}

Since its inception in the 80 's, capillary electrophoresis has matured into a well-established separation technique, actually encompassing a family of electrodriven techniques with distinct separation mechanisms and selectivity, performed in a single capillary column. In this work, the versatility of capillary electrophoresis in handling materials from a diversity of chemical classes and complex sample matrices is illustrated by representative applications in the clinical, forensic, cosmetological, environmental, nutritional and pharmaceutical areas, grouping together our own research interests and results.

Keywords: capillary electrophoresis, ions, hemoglobin, morphine, aldehydes, pesticides, plant secondary metabolites, protein hydrolysate, AIDS drug cocktail

\section{Introduction}

Electrophoresis is the separation of charged molecules based on differential migration in an electric field. Historically, it was introduced in the early 1930's with the moving-boundary method of Tiselius, for the separation of human serum into some of its constituent proteins. For this pioneering work, Tiselius was awarded a Nobel prize in 1948. Since then, electrophoresis has held a unique position among the techniques for separation of biomolecules. But only in the last two decades, with the implementation of the capillary techniques, has electrophoresis evolved from a manually intensive to a fully automated format and gained acceptance in the analytical métier. ${ }^{1}$

At the present time, capillary electrophoresis (CE) encompasses a family of electrodriven techniques with

* e-mail: mfmtavar@iq.usp.br distinct separation mechanisms and selectivities. ${ }^{2}$ Relevant aspects of the technique such as high efficiency, high resolving power, high speed, full automation and a variety of injection based pre-concentration schemes and detection modes have all been extensively investigated. ${ }^{3}$ In addition to these technological developments, much research has been directed towards demonstrating the versatility of $\mathrm{CE}$ for routine applications. ${ }^{2,3}$

In this work, the versatility of capillary electrophoresis is illustrated by representative applications in several areas: clinical/forensic (hemoglobins in hemolysate, ketoacid metabolites in serum and opiates in hair), cosmetological (alkaloids, xanthines, terpenes and phenolic compounds in herbal extracts and essential oils and electrophoretic profile and aminogram of protein hydrolysates), environmental (aldehydes in air and vehicular emission and pesticides in vegetables), nutritional (carboxylic acids in wine and carbohydrates in yogurt) and pharmaceutical (analysis of anti-HIV drugs). 


\section{Experimental}

\section{Instrumentation}

All experiments were conducted in capillary electrophoresis systems, either model P/ACE 5510 from Beckman Instruments (Fullerton, CA, U.S.A.) or model $\mathrm{HP}^{3 \mathrm{D}} \mathrm{CE}$ from Agilent Technologies (Palo Alto, CA, U.S.A.). The P/ACE unit was equipped with a filter-carrousel UV detector, while the $\mathrm{HP}^{3 \mathrm{D}} \mathrm{CE}$ unit was equipped with a diode array detector. Both systems had temperature control devices, maintained at $25-30{ }^{\circ} \mathrm{C}$ and data acquisition and treatment software supplied by the manufacturer. Uncoated fused-silica capillaries (Polymicro Technologies, Phoenix, AZ, U.S.A.) were used in all experiments except for the hemoglobin analyses, where a dimethylpolysiloxane coated fused-silica capillary (DB-1, J\&W Scientific, Folsom, CA, U.S.A.) with dimensions of $27 \mathrm{~cm}$ total length, $20 \mathrm{~cm}$ effective length, $50 \mu \mathrm{m}$ i.d. and $0.20 \mu \mathrm{m}$ coating thickness was used. At the beginning of the day, regular capillaries were typically washed with a $1 \mathrm{~mol} \mathrm{~L}^{-1} \mathrm{NaOH}$ solution (high pressure, $5 \mathrm{~min}$ ), followed by deionized water (5 min) and electrolyte (30 $\mathrm{min})$. In between runs, the capillaries were usually reconditioned by a flush with the electrolyte solution (high pressure, $2 \mathrm{~min}$ ). At the beginning of the day, the coated capillary was conditioned by a flush of methanol followed by deionized water $(1.38$ $\mathrm{x} 10^{2} \mathrm{kPa}$ for $10 \mathrm{~min}$, each flush). In between runs, the coated capillary was just replenished with fresh ampholyte working solution ( 2 min flush). At the end of the day, the coated capillary was washed with deionized water, methanol, and dried by a flush of nitrogen $\left(1.38 \times 10^{2} \mathrm{kPa}\right.$, 5 min each flush). Specific injection and detection conditions are given in the figure legends.

\section{Reagents, standards and solutions}

All reagents were of analytical grade, the solvents were of chromatographic purity and the water was purified by deionization (Milli-Q system, Millipore, Bedford, MA, U.S.A.). Most of the standards were supplied by Fluka-SigmaAldrich (St. Louis, MO, U.S.A.). A few specific standards were supplied by Extrasynthèse (Genay, France; flavonoid glucosides), Radian International (Austin, Texas, U.S.A.; opiates), and pharmaceutical laboratories participating in the Brazilian government DST/AIDS program. Ampholyte solutions in the $\mathrm{pH}$ range 6-8 and 3-10 were supplied by Amersham Pharmacia Biotech (Uppsala, Sweden) and a 4\% methylcellulose stock solution was supplied by Applied Biosystems (Foster City, CA, U.S.A.). Electrolyte composition is compiled in each figure legend.
Samples

Clinical/forensic samples. Serum samples from diabetic patients were kindly provided by the Hospital Israelista Albert Einstein (São Paulo, SP, Brazil) and stored at $-20{ }^{\circ} \mathrm{C}$ until analysis. For the analysis of hemoglobins, whole blood samples were provided by the Centro de Patologia Clínica Campana (São Paulo, SP, Brazil). The whole blood samples were centrifuged and $15 \mu \mathrm{L}$ of the deposited red cells were collected and transferred into a vial containing $200 \mu \mathrm{L}$ of the hemolyzing reagent (0.05 mol L-1 EDTA and $\left.0.010 \mathrm{~mol} \mathrm{~L}^{-1} \mathrm{KCN}\right)$. The vial was then mixed in a vortex and the resulting hemolysate was stored at $-20^{\circ} \mathrm{C}$ until analysis. For the analysis of opiates, hair samples from patients under medication for pain control (morphine) were kindly donated by the Grupo da Dor do Hospital das Clínicas (FMUSP, São Paulo, SP, Brazil). Hair samples were hydrolyzed under acidic solution (0.25 mol L $\left.\mathrm{L}^{-1} \mathrm{HCl}\right)$, overnight, at $45{ }^{\circ} \mathrm{C}$. The hair hydrolysate was pre-concentrated in an ion-exchanger SPE cartridge (Oasis MCX, Waters Corp., Milford, MA, U.S.A.). A $5 \% \mathrm{NH}_{4} \mathrm{OH}$ methanolic solution was used to quantitatively elute morphine from the MCX cartridge.

Cosmetological samples. Protein hydrolysate of silk fiber (SILKION ${ }^{\circledR}$, batch FS-63990998), and herbal extracts of quinine bark, (Chinchona officinalis, QUINA HG ${ }^{\circledR}$, batch FS-95640201), chamomile (Matricaria recutita L., CAMOMILA HG ${ }^{\circledR}$, batch FS-75250899), mate (Ilex paraguariensis, ERVA MATE $\mathrm{HG}^{\circledR}$, batch FS-84270500) and propolis (PROPOLIS HG ${ }^{\circledR}$, batch FS10590-1001) were obtained from a local industry (Farma Service Indústria Farmacêutica SA, São Paulo, SP, Brazil). Geranium (Pelargonium graveolens) essential oil was obtained from a local industry (Petite Marie Química Fina Ind. e Com. Ltda., São Paulo, SP, Brazil).

Environmental samples. Aldehydes were sampled directly from the exhaust pipe tail of an ethanol-based fuel vehicle with the aid of a vacuum pump, operating at the flow rate of $0.5 \mathrm{~L} \mathrm{~min}^{-1}$. The exhaust gases were absorbed by two $10 \mathrm{~mL}$ aliquots of a $2 \mathrm{mmol} \mathrm{L}^{-1}$ bisulfite solution, contained in two impingers, arranged in series and cooled by ice baths. Approximately $133 \mathrm{~L}$ of indoor laboratory air was sampled by forcing air through C-18 cartridges, pre-conditioned with a $0.81 \mathrm{mmol} \mathrm{L}^{-1} 4$ hydrazine benzoic acid solution. Samples were eluted from the cartridge with 1:1 methanol:water. For the analysis of pesticides, pieces of carrots ( $c a .15 \mathrm{~g}$ ) were blended in a mixture of solvents (1:1:1 acetone:petroleum ether:dichloromethane) containing $4 \mathrm{~g} \mathrm{NaCl}$. The organic layer was separated, dried with $\mathrm{Na}_{2} \mathrm{SO}_{4}$ and evaporated under nitrogen. The extract was then applied to a SPE 
cartridge (Strata, $\mathrm{NH}_{2}$, Phenomenex, Labtron, São Paulo, SP, Brazil). The cartridge was dried with nitrogen and the analytes were eluted with $7 \mathrm{~mL}$ of a mixture of 99:1 $\mathrm{CH}_{2} \mathrm{Cl}_{2}: \mathrm{MeOH}$. The eluate was dried and ressuspended in $500 \mu \mathrm{L}$ of a $30 \mathrm{mmol} \mathrm{L}^{-1}$ tetraborate solution.

Food samples. Red wine, strawberry yogurt, fish oil and enriched milk were obtained from local grocery stores. A parenteral solution (Nutrisource) was obtained from Novartis Consumer Health Ltda, (São Paulo, SP, Brazil). For the analysis of fatty acids, samples were saponified by treating 200-500 mg of the sample with $5 \mathrm{~mL}$ of a methanolic $\mathrm{NaOH}$ solution $\left(0.5 \mathrm{~mol} \mathrm{~L}^{-1}\right)$ at $75-80^{\circ} \mathrm{C}$ for $25 \mathrm{~min}$.

\section{Results and Discussion}

\section{Clinical/forensic applications}

Application of capillary electrophoresis to the determination of several metabolites related to Diabetes Mellitus has been focus of our research recently. ${ }^{4,5}$ Diabetes Mellitus is considered a class of diseases that exhibits as a sole characteristic, intolerance to glucose. This condition results from a deficiency in the secretion or action of a pancreatic hormone, insulin, causing severe metabolic disorders. Typically, high levels of glucose are found in blood, which promote the glycosylation of hemoglobin, the oxygen carrying protein found in red blood cells, giving the so called glycated hemoglobin $\left(\mathrm{HbA}_{1 \mathrm{c}}\right) . \mathrm{HbA}_{1 \mathrm{c}}$ can be used as indicative of the glucose concentration in the blood during the period of time red cells were exposed to it. Therefore, for clinical diagnostic purposes and mostly for monitoring the patient's metabolic status, the determination of $\mathrm{HbA}_{1 \mathrm{c}}$ has been strongly considered. ${ }^{6}$ Figure 1A illustrates the separation of $\mathrm{HbA}_{1 \mathrm{c}}$ among other hemoglobins and variants using capillary isoelectric focusing (cIEF) with chemical mobilization. An interesting feature of such analysis is that resolution of hemoglobins differing by less than $0.03 \mathrm{pI}$ units is readily achieved.

Another metabolic disorder associated with Diabetes Mellitus is the excessive production of the so called ketonic bodies (pyruvic, acetoacetic acids, acetone and the reduced forms: lactic and $\beta$-hydroxybutyric acids). The increase in production of ketonic bodies causes an imbalance in the anion gap, given by the expression: $\left[\mathrm{Na}^{+}\right]+\left[\mathrm{K}^{+}\right]-[\mathrm{Cl}]-$ $\left[\mathrm{HCO}_{3}^{-}\right]$. For clinical diagnostics, each of the ions of the anion gap as well as the ketonic bodies are determined by distinct methodologies. Capillary electrophoresis can be used as a single analytical technique for the evaluation of the ketoacidosis condition in diabetic patients. Figure 1B illustrates the separation of pyruvate, lactate, acetoacetate and $\beta$-hydroxybutyrate in human blood serum. When indirect detection is used, peak identity is confirmed solely by spiking techniques. Analysis of other cations and anions involved in the anion gap is also possible using capillary electrophoresis. ${ }^{\text {? }}$

The opiates morphine, codeine, heroin and fentanyl have been used therapeutically and/or consumed illicitly for many years. During therapeutic monitoring, drug levels in blood or saliva are usually measured to adjust posology. Alternatively, hair specimens can be tested. Hair is a popular specimen for drug analysis as it is relatively noninvasive to collect, and provides a historical record of exposure, even though it does suffer from concentration variability due to hair type and drug affinity. Hair is a complex tissue, an annex of skin, originating from a
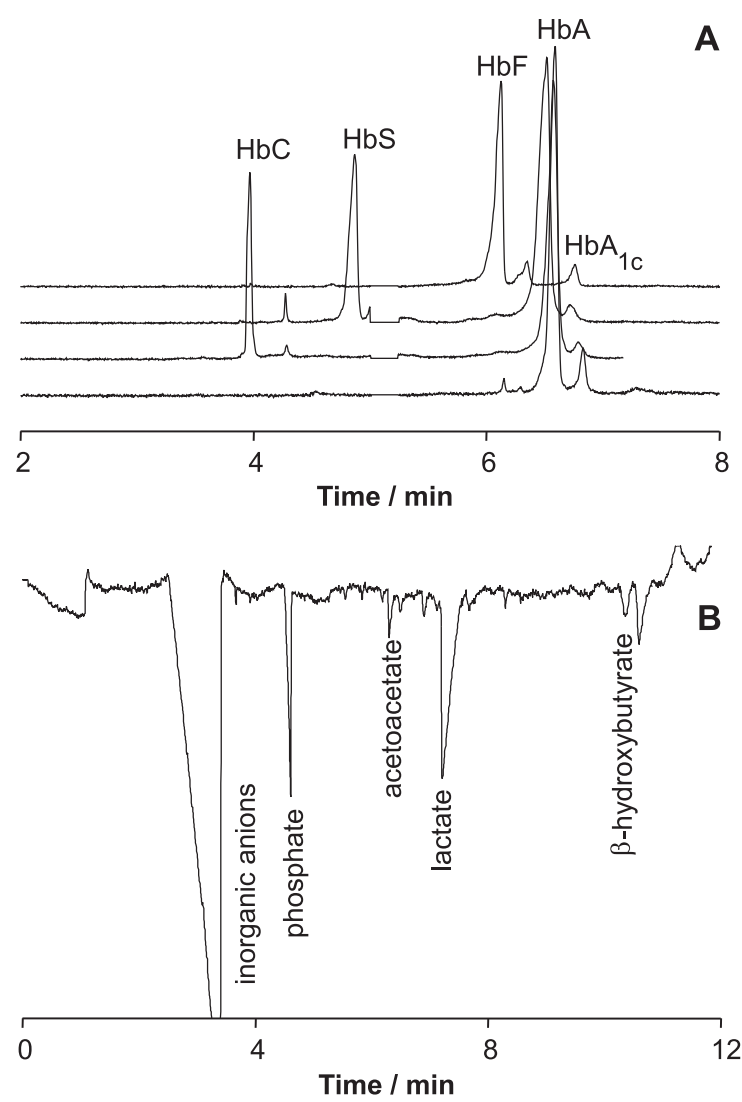

Figure 1. Clinical Applications of Capillary Electrophoresis: analysis of hemoglobins and its variants in hemolysate (A) and ketoacids in human serum (B). For the analysis of hemoglobin, an isoelectric focusing methodology with a coated capillary using chemical mobilization was used. Catholyte solution during focalization: 0.040 mol L ${ }^{-1} \mathrm{NaOH}$. Catholyte solution during mobilization: $0.040 \mathrm{~mol}$ $\mathrm{L}^{-1} \mathrm{NaOH}$ containing $0.080 \mathrm{~mol} \mathrm{~L}^{-1} \mathrm{NaCl}$. Anolyte solution: 0.100 mol L $\mathrm{L}^{-1}$ phosphoric acid. Working ampholyte solution: $4 \%(\mathrm{pH} 6-$ 8:pH $3-10,10: 1, \mathrm{v} / \mathrm{v})$ in $0.30 \%$ methylcellulose. Hydrodynamic sample injection: $3.5 \mathrm{kPa}$ for $10 \mathrm{~s}$. Focalization step: $30 \mathrm{kV}$ during $5 \mathrm{~min}$. Chemical mobilization step: $30 \mathrm{kV}$ during $3 \mathrm{~min}$. For the analysis of the ketoacids, the conditions were: $5 \mathrm{mmol} \mathrm{L}^{-1} 3,5$ dinitrobenzoate, $0.1 \mathrm{mmol} \mathrm{L}^{-1} \mathrm{CTAB}, \mathrm{pH} 3.5$; hydrodynamic injection of $3.4 \mathrm{kPa} / 2 \mathrm{~s}$; applied voltage of $-15 \mathrm{kV}$; indirect detection at $254 \mathrm{~nm}$ and $25{ }^{\circ} \mathrm{C}$. 
germination center located in the hair follicle, where matrix cells are in active proliferation. Drug incorporation into hair occurs from the blood circulation in a capillary located close to the germination center, but also from sebum and sweat secreted by glands associated with the hair root. After embedding in the hair matrix, drugs are protected from degradation and metabolism, lasting unaltered for a long time in this issue.

Hair was first used to monitor chronic ingestion of toxic substances such as heavy metals. But at the present time, hair analysis is widely employed for the detection of drugs of abuse in various contexts (violation of laws on narcotics, probation and parole monitoring, assessment of compliance with detoxification treatments, revocation of driving license, etc).

From the analytical point of view, hair poses specific problems, including sample collection, preparation and extraction. ${ }^{8}$ Hair analysis mainly relies on immunometric screenings followed by GC or HPLC confirmation methods. Our research interests comprise the optimization of the separation of several opiates and metabolites by $\mathrm{CE}$, as compiled in Figure 2A, as well as the analysis of morphine in hair samples of patients suffering from medullar lesion, receiving morphine via implantable intrathecal systems. Figure 2B shows the results of a three-step methodology developed in our laboratory for hair analysis of such a patient: hydrolysis, ion-exchanger extraction followed by $\mathrm{CE}$ analysis in a low $\mathrm{pH}$ phosphate buffer. Peak identity was confirmed by spiking techniques.

\section{Cosmetic applications}

The demand of cosmiatric products for skin care and hair treatment based on herbal extracts and essential oils has increased remarkably. Considering the complex nature of such matrices, well-developed methodologies for quality control during industrial processing of the extracts and their storage as well as to monitor adulterations in raw materials and final products are highly desirable and the normalization of quality control procedures has been the focus of Brazilian legislation recently. Liquid chromatography (HPLC) and/or gas chromatography (GC-FID, GCMS) are the techniques of choice for such analyses. Capillary electrophoresis has been considered an appropriate alternative for the analytical evaluation of several different classes of naturally occurring compounds in herbal extracts and essential oils. ${ }^{9}$ Developing analytical protocols able to investigate systematically the overall composition of a given extract and/or essential oil has become a strong area of interest in our research group. ${ }^{10} \mathrm{In}$ Figure 3, a series of electropherograms illustrating the
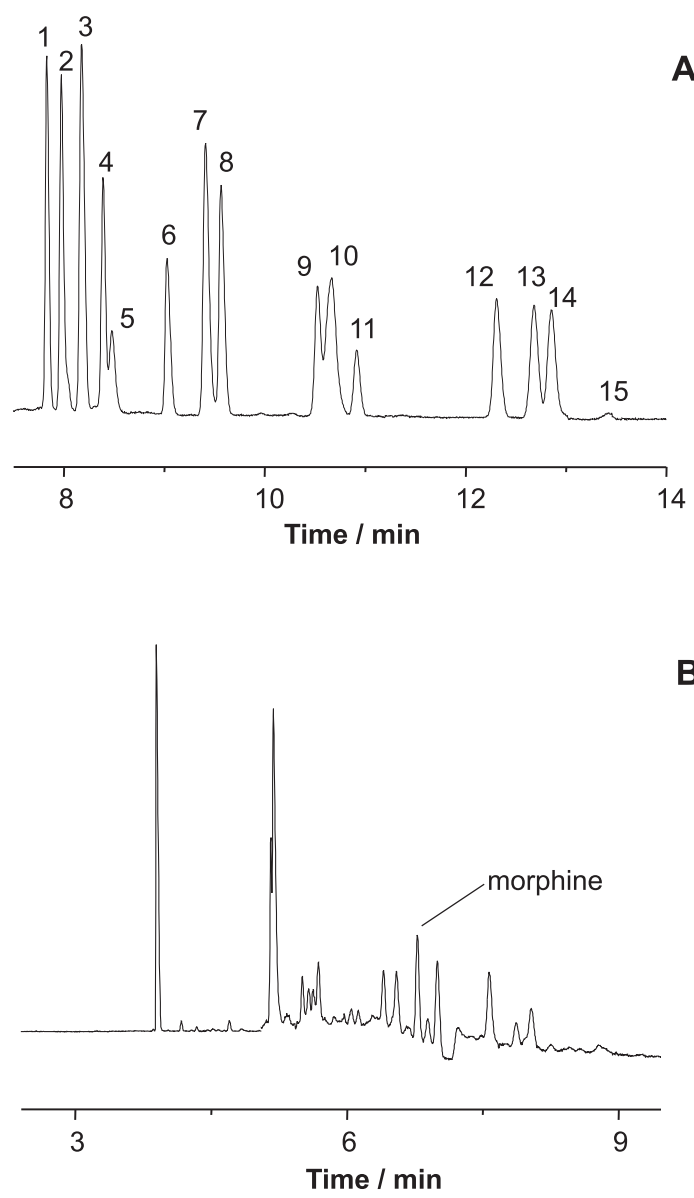

Figure 2. Forensic Applications of Capillary Electrophoresis: opiates standards (A) and the identification of morphine in a hair sample (B). The standards: petidine (1), 6-acetyl-morphine (2), morphine3b-glucuronide (3), morphine (4), codeine (5), tramal (6), naloxon (7), methadone (8), pentazocine (9), nalorphine (10), 6-acetyl-codeine (11), fentanyl citrate (12), alfentanyl $\mathrm{HCl}$ (13), sufentanyl citrate (14) and norfentanyl (15) were analyzed in $60 \mathrm{mmol} \mathrm{L}^{-1}$ phosphate buffer, $\mathrm{pH} 2.5$, containing $8 \mathrm{mmol} \mathrm{L}^{-1} \beta$-cyclodextrin and $4 \%$ methanol. Other conditions: electrokinetic injection of 10 $\mathrm{kV} / 5 \mathrm{~s}$, applied voltage of $30 \mathrm{kV}$, detection at $200 \mathrm{~nm}$ and $20^{\circ} \mathrm{C}$. The hair sample was analyzed in a $20 \mathrm{mmol} \mathrm{L}^{-1}$ phosphate buffer, $\mathrm{pH} 2.5$, with injection of $5 \mathrm{kV} / 5 \mathrm{~s}$, applied voltage of $25 \mathrm{kV}$, detection at $200 \mathrm{~nm}$ and $30{ }^{\circ} \mathrm{C}$

separation of important classes of plant secondary metabolites in cosmiatric products is presented. In such matrices, peak identity is always confirmed by spiking techniques as well as by inspection of the on-line acquired UV- spectra.

Proteins have been used in cosmetic formulations for more than twenty years. Proteins from animal sources and, more recently, from marine and vegetable sources, are now commercially available in a variety of structures and a wide range of molar masses. Both vegetable and animal proteins differ by many factors including not only the specific origin, but also, size, electrical charge, polarity of the functional side groups and the type of attached 

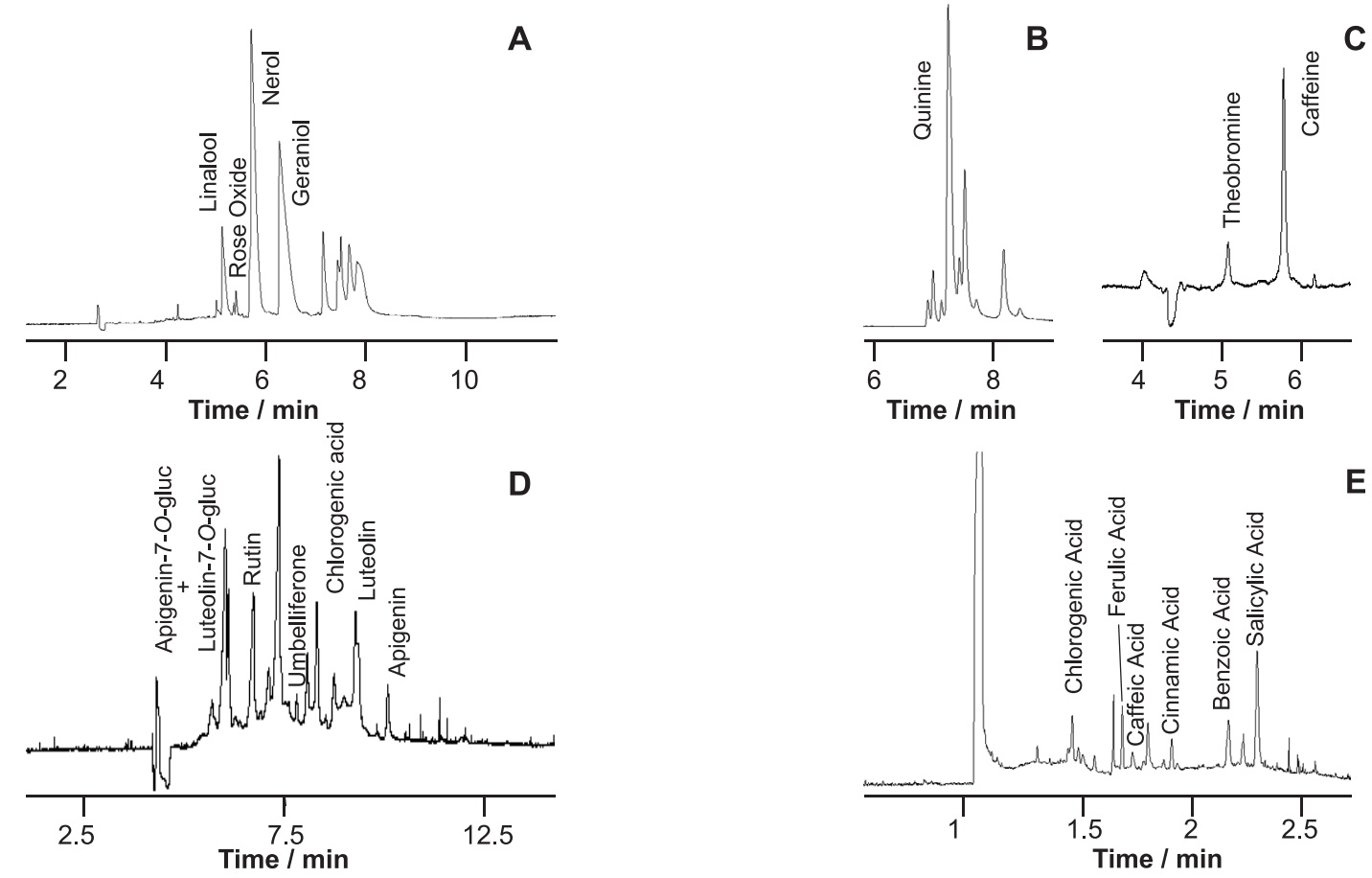

Figure 3. Cosmetic Applications of Capillary Electrophoresis: analysis of secondary plant metabolites in herbal extracts and essential oils. (A) Terpenes in geranium oil, (B) Alkaloids in Quinine bark, (C) Xanthines in Mate, (D) Flavonoids and Phenolic compounds in Chamomile; (E) Phenolic Acids in Propolis. For the analysis of terpenes, a $20 \mathrm{mmol} \mathrm{L}^{-1}$ tetraborate solution, pH 9, containing $15 \mathrm{mmol} \mathrm{L}^{-1}$ SDS was used, with injection of $2.5 \mathrm{kPa} / 3 \mathrm{~s}, 35 \mathrm{kV}$ of applied voltage and detection at $200 \mathrm{~nm}$. For the analysis of alkaloids, a $20 \mathrm{mmol} \mathrm{L}^{-1} \mathrm{phosphate} \mathrm{buffer,} \mathrm{pH}$ 2.5 , containing $0.15 \%$ TEA was used; with injection of $2.5 \mathrm{kPa} / 3 \mathrm{~s}, 25 \mathrm{kV}$ of applied voltage and detection at $200 \mathrm{~nm}$. For the analysis of

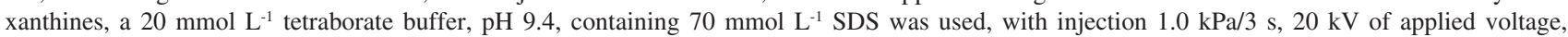
and detection at $274 \mathrm{~nm}$. For the analysis of flavonoids and phenolic compounds, a $20 \mathrm{mmol} \mathrm{L}^{-1}$ tetraborate buffer, $\mathrm{pH} 10$, was used; with injection of $2.5 \mathrm{kPa} / 3 \mathrm{~s}, 25 \mathrm{kV}$ of applied voltage and detection at $337 \mathrm{~nm}$. For the analysis of phenolic acids, a $10 \mathrm{mmol} \mathrm{L}^{-1}$ phosphate buffer, $\mathrm{pH} 7$, was used; with injection of $2.0 \times \mathrm{kPa} / 4 \mathrm{~s}, 25 \mathrm{kV}$ of applied voltage and detection at $200 \mathrm{~nm}$.

moieities (quaternary amines, fatty acids, silicones, etc). In general, the functional properties of proteins responsible for hair repair treatment and hair conditioning depend on one or more of the following physical characteristics: substantivity, penetration, film formation, moisture retention and gloss. Specific functional claims made for proteins in skin-care applications include moisturization, improved elasticity, a soft and silky feel, a skin firming effect through film formation and relief from chapping and irritation due to detergents. However, not all proteins exhibit all of these characteristics to the same extent. For instance, high molar mass proteins are better at film formation, while proteins of low molar mass are better at moisture retention.

Lately, the use of the high-molar mass native collagen, among other proteins of animal origin, has been strongly questioned as a consequence of the publicity around Bovine Spongiform Encephalopathy (BSE). Therefore, the use of proteins originating from vegetable sources represents a new trend in the market of personal care products. However, vegetable proteins are typically insoluble in water and in order to make possible their use in cosmetic preparations, a hydrolysis procedure must be carried out. Our research interests comprise the characterization of protein hydrolysates of diverse origin (keratin, silk fiber, milk, soybean, fish tissue, and cattle leather), in terms of electrophoretic profile, molar mass distribution and amino acid contents. ${ }^{11}$ In Figure 4A, the electrophoretic profile of the fraction containing the most hydrophilic peptides in a silk fiber hydrolysate is presented. The hydrolysate was submitted to solid-phase extraction prior to injection. In Figure 4B, the aminogram of the intact product is depicted. Since the hydrolysis was conducted in acidic medium, a large number of amino acids can be visualized.

\section{Environmental applications}

Low molar mass aldehydes are among the most abundant organic gases in atmosphere. A number of aldehydes are emitted to the atmosphere by indoor (plastic, foam insulation, lacquers etc.) and outdoor sources 


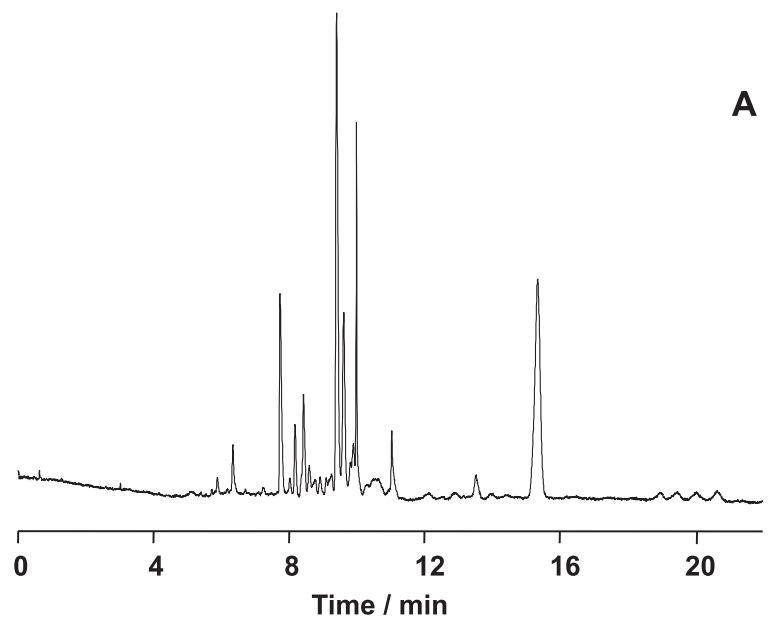

B

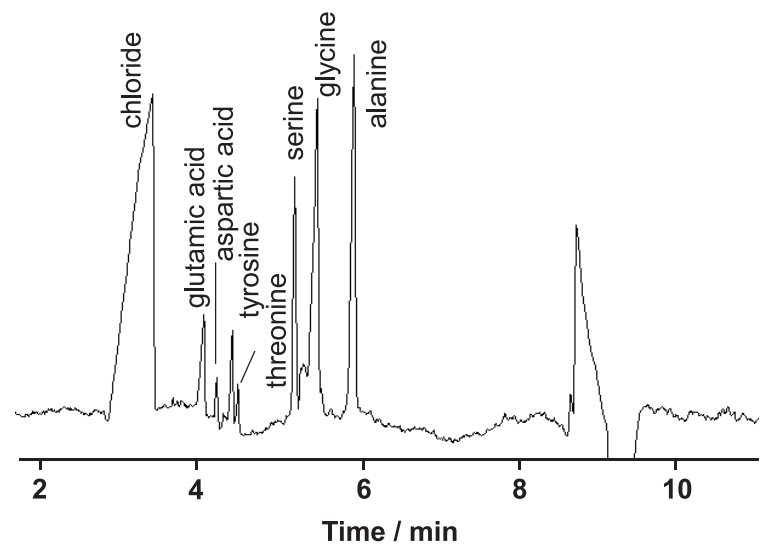

Figure 4. Cosmetic Applications of Capillary Electrophoresis: analysis of protein hydrolysates. (A) Fingerprint of peptides in SILKION ${ }^{\circledR}$ (silk fiber hydrolysate); (B) Aminogram of SILKION ${ }^{\circledR}$. For the fingerprint, a $20 \mathrm{mmol} \mathrm{L}^{-1}$ phosphate buffer, $\mathrm{pH} 2.5$, was used, with injection 5.0 $\mathrm{kPa} / 1 \mathrm{~s}, 25 \mathrm{kV}$ of applied voltage and detection at $200 \mathrm{~nm}$. For the aminogram, a $40 \mathrm{mmol} \mathrm{L}^{-1}$ phenol solution, $\mathrm{pH} 10$, containing 0.2 mmol L-1 CTAB and $20 \%$ methanol was used, with injection of $3.4 \mathrm{kPa} /$ $3 \mathrm{~s},-20 \mathrm{kV}$ applied voltage and detection at $200 \mathrm{~nm}$.

(industrial plants, cooking fumes, vehicular emission etc.). Aldehydes are important precursor compounds of photochemical smog and their chemistry has been associated with the generation of harmful free radicals, peroxyacetyl nitrate (PAN) and ozone. Because of adverse effects of aldehydes on health, prevention and control strategies of these pollutants have demanded wellcharacterized and highly sensitive analytical methodologies. In this context, capillary electrophoresis has become an interesting alternative technique for environmental analysis due to advantageous performance characteristics. Our research interests in environmental analysis started with the evaluation of carboxylic acids and metallic cations in vehicular emission and aerosol particulates. ${ }^{12,13}$ Lately, we been investigating several analytical possibilities for the $\mathrm{CE}$ evaluation of aldehydes in atmospheric air. ${ }^{14-16}$ Figure 5 presents two analytical possibilities for the analysis of aldehydes by free solution capillary electrophoresis: separation of anionic bisulfite-aldehyde adducts in vehicular emission and 4-hydrazine benzoic acid (HBA)aldehyde derivatives in indoor air samples.

Pesticide is a generic term used to describe a large number of widely differing organic compounds employed in the control, prevention and elimination of plagues that attack crops and herds as well as being vectors of diseases in humans. The use of pesticides constitutes an important aspect of modern agriculture, with unquestionable impact on crop production. Due to their wide use in agriculture, associated with their persistence and toxicity, these
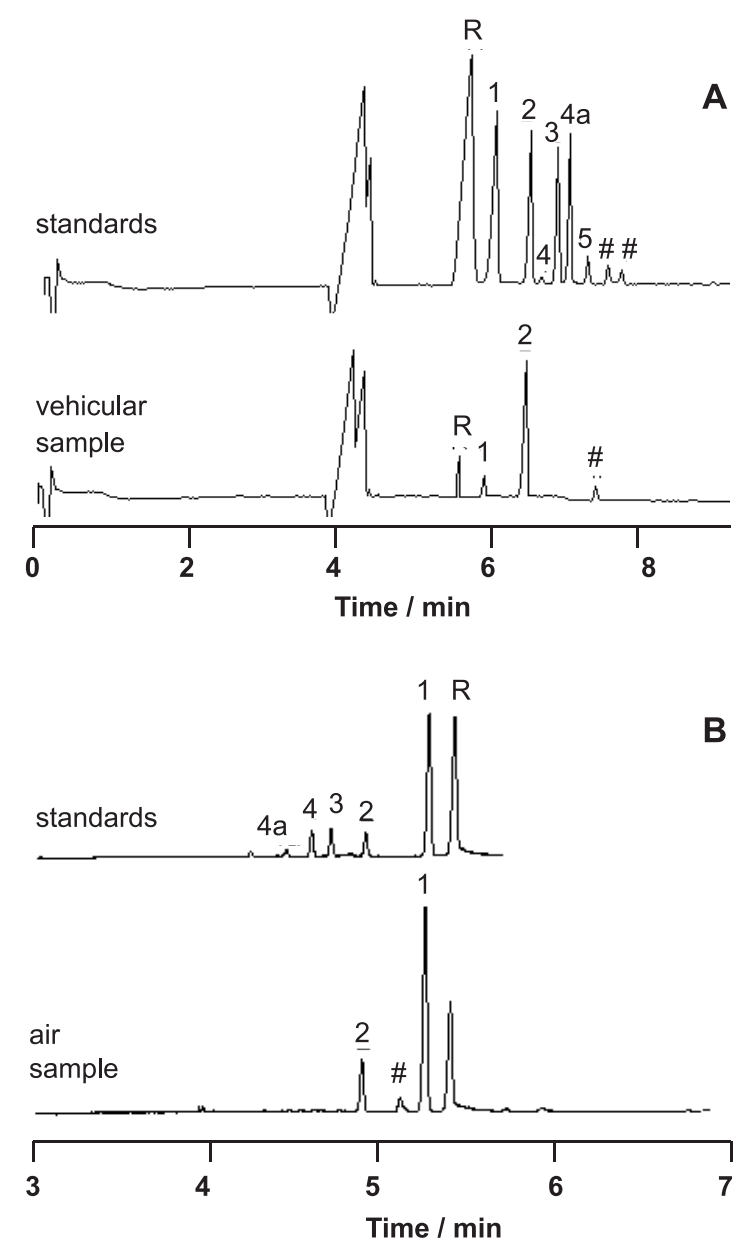

Figure 5. Environmental Applications of Capillary Electrophoresis: analysis of aldehydes as bisulfite adducts (A) in car pipe exhaustion gases, and as HBA derivatives (B) in indoor air samples. (A) Electrolyte: $10 \mathrm{mmol} \mathrm{L}^{-1}$ 3,5-dinitrobenzoic acid solution $(\mathrm{pH} 4.5)$ containing $0.20 \mathrm{mmol} \mathrm{L}^{-1} \mathrm{CTAB}$; injection, $17 \mathrm{kPa} / 1.5 \mathrm{~s},-15 \mathrm{kV}$, indirect detection at $254 \mathrm{~nm}$. (B) Electrolyte: $40 \mathrm{mmol} \mathrm{L}^{-1}$ borate buffer solution (pH 9); injection $2.5 \mathrm{kPa} / 20 \mathrm{~s}, 25 \mathrm{kV}, 290 \mathrm{~nm}$. Peak Labels: (1) formaldehyde, (2) acetaldehyde, (3) propionaldehyde, (4,4a) acrolein, (5) benzaldehyde, (R) is the excess reagent and (\#) are impurities. 
compounds are a source of environmental contamination, presenting serious hazards to human health, through incorporation of residues in waters, soils and crops. Therefore, the continuous monitoring of pesticide residues in environmental samples is of great importance and demands high efficiency, unique selectivity and highly sensitive techniques. Capillary electrophoresis in its various modes of operation coupled to on-line and offline pre-concentration procedures has proven to be a resourceful alternative for the analysis of pesticides. ${ }^{17}$ Our research interests in this area comprise the development of methodologies for on-line pre-concentration and analysis of pesticides in fruits and vegetables. In Figure 6 the separation of pesticides from different classes (atrazine, propazine, simazine, carbendazin, diuron, linuron, chlorpyriphos and pyrazophos) is presented as well as the inspection of pesticides in a carrot sample.
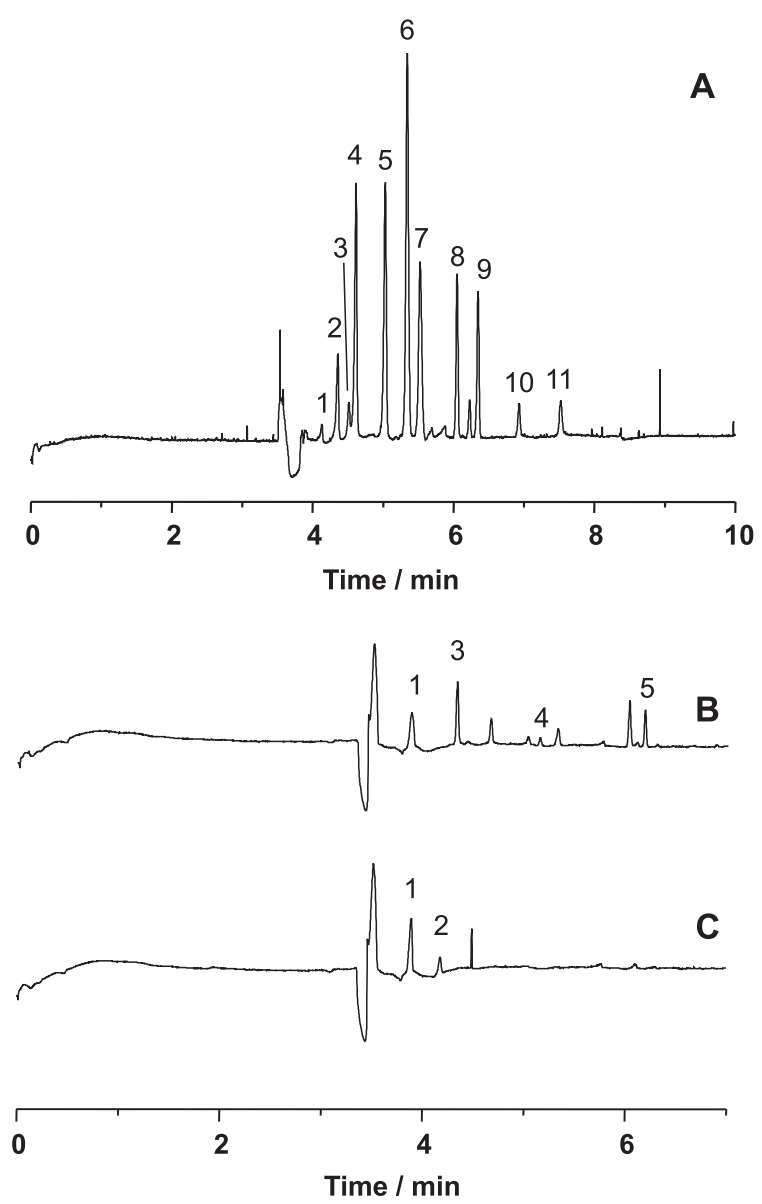

Figure 6. Environmental Applications of Capillary Electrophoresis: analysis of pesticides standards (A) and pesticides in carrot (B, spiked skin, $\mathrm{C}$, carrot core, in natura). Electrolyte: $20 \mathrm{mmol} \mathrm{L}^{-1}$ tetraborate, $10 \mathrm{mmol} \mathrm{L}{ }^{-1}$ SDS, $12 \mathrm{mmol} \mathrm{L}^{-1}$ trimethylcyclodextrin, $2 \mathrm{mmol} \mathrm{L}^{-1}$ Brij 35 and $10 \%$ methanol; injection, $2.5 \mathrm{kPa} / 8 \mathrm{~s}, 27 \mathrm{kV}$ applied voltage, $27{ }^{\circ} \mathrm{C}, 214 \mathrm{~nm}$. Peak legends: (1) aldicarb, (2) carbendazin, (3) carbofuran, (4) simazine, (5) atrazine, (6) carbaryl, (7) propazine, (8) diuron, (9) linuron, (10) pyrazophos and (11) chlorpyriphos.

\section{Nutritional applications}

Capillary electrophoresis can make an important contribution in the context of wine production, since it can replace several costly techniques currently used in enology laboratories, including those for organic acids. Many wineries monitor the malo-lactic fermentation process during production of fine wines, performing frequent sampling. Until now most labs have depended on two separate enzymatic methods for analysis of malic and lactic acids and the classical Cash still method for acetic acid. Enzymatic methods are expensive, while Cash still distillations are time consuming and prone to error. In our research group, the contents of mono- di- and tri-carboxylic acids in several spirits including wine and beer, drinkable formulations and fruit juices has been determined by capillary electrophoresis. Figure 7A presents the CE separation of selected carboxylic acids in red wine using indirect detection.
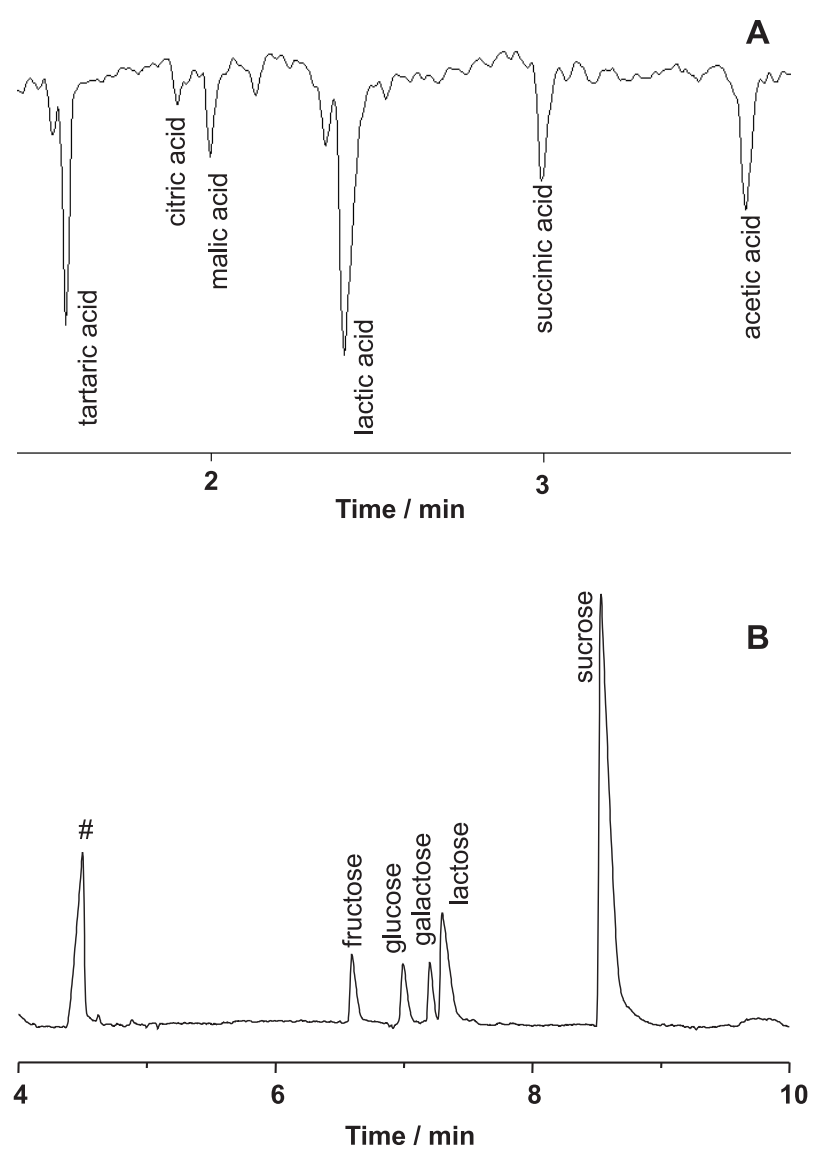

Figure 7. Nutritional Applications of Capillary Electrophoresis: analysis of carboxylic acids in wine (A) and carbohydrates in yogurt (B). (A) $10 \mathrm{mmol} \mathrm{L}^{-1} 3,5$-dinitrobenzoic acid with $0.2 \mathrm{mmol} \mathrm{L}^{-1}$ CTAB, pH 3.6; $254 \mathrm{~nm}$. (B) $15 \mathrm{mmol} \mathrm{L}^{-1}$ sorbate, $0.5 \mathrm{mmol} \mathrm{L}^{-1}$ $\mathrm{CTAB}$ and $35 \mathrm{~mol} \mathrm{~L} \mathrm{~L}^{-1} \mathrm{NaOH}$; injection $3.4 \mathrm{kPa} / 15 \mathrm{~s}, 30^{\circ} \mathrm{C},-18 \mathrm{kV}$ and $254 \mathrm{~nm}$. (\#) is a non-identified peak. 
The analysis of carbohydrates is considerably important in the fields of nutrition, biology and food science. Fructose, glucose, maltose and sucrose are present in a variety of foods and their quantitative determination allows the evaluation of sample authenticity, quality control of food products and possible microbiological alterations during product storage. By raising the electrolyte $\mathrm{pH}$, carbohydrates can acquire a negative charge and be easily characterized by CE under indirect detection..$^{18}$ Figure 7B presents the electropherogram of a strawberry yogurt sample showing the discrimination of a few carbohydrates.

The determination of fatty acids is important for the chemical characterization of eatable oils and fats and in the quality control of dairy products. Classical methodologies for fatty acids include GC and HPLC. In the former technique, volatile derivatives are required for the longer chain solutes and analysis time is relatively long. In HPLC analysis, UV-absorbing adducts are usually employed. In both cases, sample manipulation is extensive, representing a long time for the total analytical procedure. Our research interests involving edible oils and fats comprise the development of novel electrolyte systems for the CE analysis of saturated-, mono- and poly-unsaturated fatty acids, ${ }^{19}$ especially those with long carbon chains, which present the greatest separation challenge. Figure 8 illustrates the separation of fatty acids in several matrices, including long chain fatty acids in fish oil and enriched milk. In the analysis of the parenteral feed formulation (Figure 8A) detection was performed indirectly. This electropherogram presents a particularly noisy baseline as compared to other indirect-detection acquired electropherograms (Figures 1B, 4B, 5A and 7A,B). In CE, noise is usually related to the electrolyte composition (ionic strength and conductivity), especially when discrepancies between analytes and the electrolyte co-ions exist.

\section{Pharmaceutical applications}

Viruses are involved in a series of chronic and degenerative diseases and are responsible for more than $60 \%$ of the diseases affecting humankind. One of the viruses most intensely studied for the scientific community is the "Human Immunodeficiency Virus (HIV), a retrovirus able to parasite the human immunological system, causing the so called "Acquired Immune Deficiency Syndrome (AIDS), the modern plague". Azidothymidine (AZT), a drug synthesized in 1964 exhibiting anti-cancer activity, was the first drug commercialized for AIDS treatment, after FDA approval in 1986. In 1996, in an international conference on AIDS held in Vancouver (Canada), a mixture of drugs
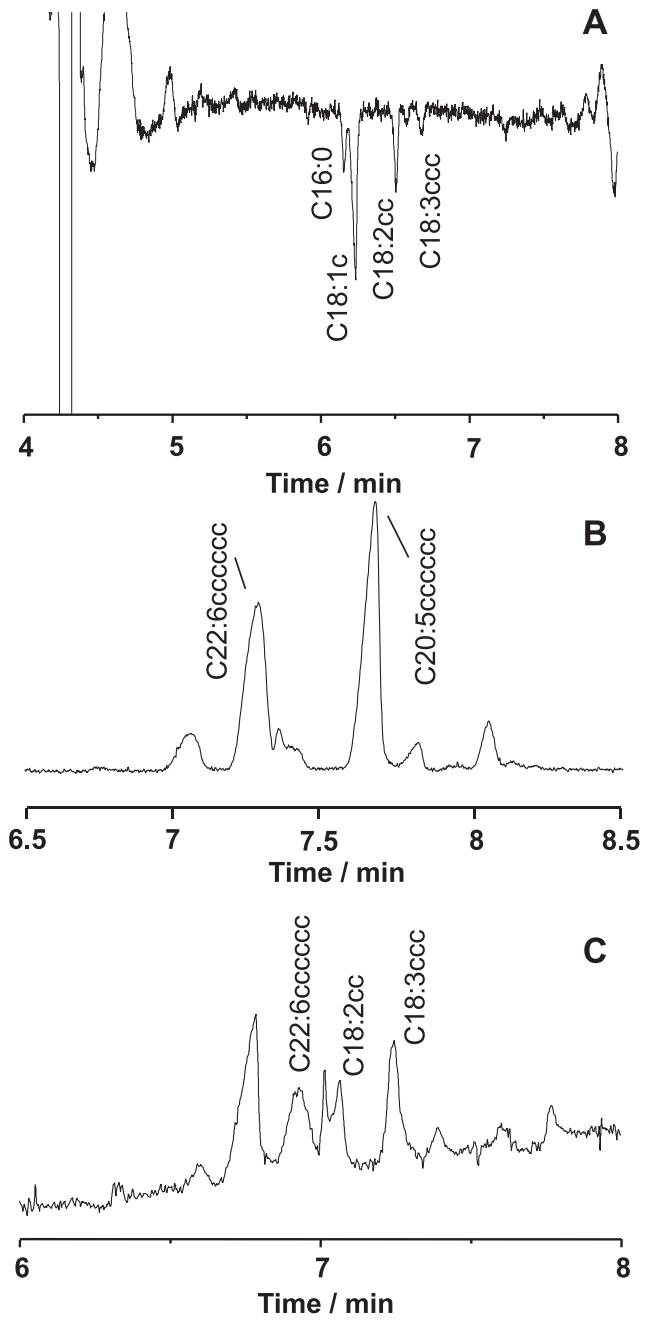

Figure 8. Nutritional Applications of Capillary Electrophoresis: analysis of oils and fats in a parenteral feed formulation (A), fish oil (B) and enriched milk (C). In (A): $5 \mathrm{mmol} \mathrm{L}^{-1}$ phosphate $\mathrm{pH} 7$ buffer containing $4 \mathrm{mmol} \mathrm{L}^{-1} \mathrm{SDBS}, 45 \% \mathrm{ACN}$ and $4 \mathrm{mmol} \mathrm{L}^{-1}$ dimethyl- $\beta$-cyclodextrin; injection $5.0 \mathrm{kPa} / 1 \mathrm{~s}, 25 \mathrm{kV}, 25^{\circ} \mathrm{C}, 224$ $\mathrm{nm}$. In (B) and (C): $10 \mathrm{mmol} \mathrm{L}^{-1}$ tetraborate $\mathrm{pH} 9.2$ buffer containing $10 \mathrm{mmol} \mathrm{L} \mathrm{m}^{-1}$ Brij 35, 25\% $\mathrm{ACN}$ and $25 \% \mathrm{MeOH}$; injection 1.25 $\mathrm{kPa} / 20 \mathrm{~s}, 30 \mathrm{kV}, 25^{\circ} \mathrm{C}, 200 \mathrm{~nm}$.

known as "cocktail" with a hundred-fold potency increase in comparison to the monotherapy was introduced to the medical community. The drugs of the cocktail are able to inhibit different steps of viral replication and are classified as: nucleoside-nucleotide inhibitors of the enzyme reverse transcriptase, non-nucleoside inhibitors of the enzyme reverse transcriptase and inhibitors of the enzyme protease. ${ }^{20}$ At the present time, there are eight drugs commercialized as nucleoside-nucleotide analogs: abacavir (ABV; Ziagen, GlaxoSmithKline), zidovudine (AZT or ZDV; Retrovir, GlaxoSmithKline), zalcitabine (ddC; Hivid, Hoffman-La-Roche Laboratories), tenofovir 
(TNV; Viread, Gilead Sciences), lamivudine (3TC; Epivir, GlaxoSmithKline), didanosine (ddI; Videx, Bristol-MyersSquibb), stavudine (d4T; Zerit, Bristol-Myers-Squibb) and adefovir (PMEA; Preveon, Gilead Sciences). Among the non-nucleosides, three drugs are commercially available: delavirdine (DLV; Rescriptor, Agouron Pharmaceuticals), efavirenz (EFV; Sustiva, DuPont Pharmaceuticals) and nevirapine (NVP; Viramune, Boehringer Ingelheim). The protease inhibitors comprise six drugs: amprenavir (APV; Agenerase, GlaxoSmithKline), indinavir (IDV; Crixivan, Merck Sharp \& Dohme), lopinavir (LPV; Kaletra, Abbot Laboratories), nelfinavir (NFV; Viracept, Agouron Pharmaceuticals), saquinavir (SQV; Fortovase and Invirase, Hoffman La Roche Laboratories) and ritonavir (RTV; Norvir, Abbott Laboratories). Our research interests in the retroviral drugs comprise the development of alternative methodologies for the analysis of active principles as well as the establishment of analytical protocols for the systematic investigation of impurities in pharmacopoeic standards. The latter is a collaborative project with the Instituto de Tecnologia em Fármacos (Far-Manguinhos, FIOCRUZ, Rio de Janeiro, Brazil). Figure 9A presents the separation of 11 drugs of the cocktail, currently in use by the Brazilian government's DST-AIDS program, establishing the potential of capillary electrophoresis for the quality control of AIDS medicines.

\section{Conclusions}

Capillary electrophoresis is a modern separation technique, with vast acceptance in the academic and industrial communities, with remarkable technological developments in the last twenty years. In Brazil, the technique is yet to reach its full potential, despite its excellent analytical performance, diversity of applications and relatively simple instrumentation.

\section{Acknowledgements}

The authors wish to acknowledge the Conselho Nacional de Desenvolvimento Científico e Tecnológico $(\mathrm{CNPq})$, the Fundação de Amparo à Pesquisa do Estado de São Paulo (FAPESP), the Coordenação de Aperfeiçoamento de Pessoal de Nível Superior (CAPES) and the Fundação Oswaldo Cruz (FIOCRUZ) of Brazil for fellowships and financial support (FAPESP 97/01320-4, 98/02446-4, 98/13437-6, 98/07643-2 and 00/04414-4). The authors are also immensely grateful to a large number of collaborators, who contributed to the present developments of many of the research areas highlighted in this work: Dr. Guilherme C. Campana and José Ari Alves
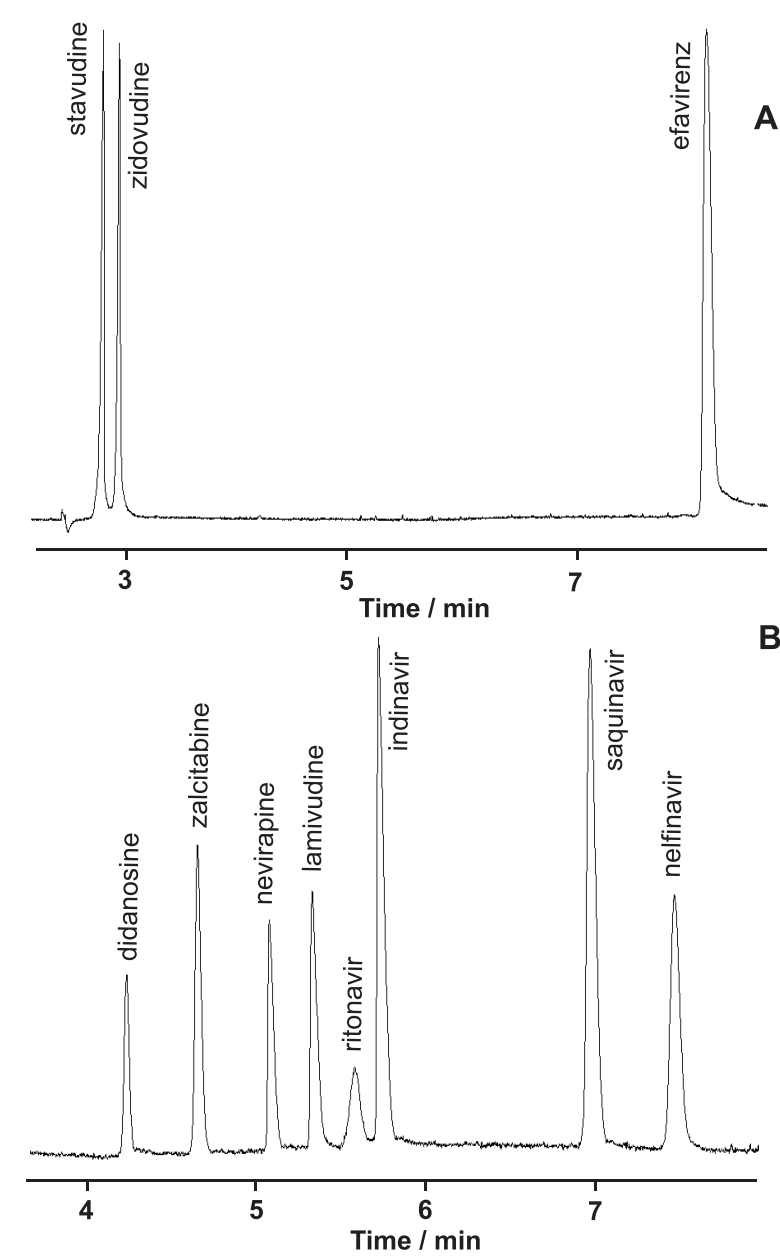

Figure 9. Pharmaceutical Applications of Capillary Electrophoresis: analysis of medicines of the anti-AIDS drug cocktail distributed by the Brazilian government's DST-AIDS program. In (A): $20 \mathrm{mmol}$ $\mathrm{L}^{-1}$ tetraborate, containing $20 \mathrm{mmol} \mathrm{L}^{-1} \mathrm{SDS}$; injection $1.0 \mathrm{kPa} / 3 \mathrm{~s}$, $20 \mathrm{kV}, 247 \mathrm{~nm}$. In (B), $20 \mathrm{mmol} \mathrm{L}{ }^{-1} \mathrm{HCl}$ in 1:1 MeOH:ACN, containing $10 \mathrm{mmol} \mathrm{L}^{-1} \mathrm{SDS}$; injection $2.0 \mathrm{kPa} / 3 \mathrm{~s}, 25 \mathrm{kV}, 200 \mathrm{~nm}$.

de Oliveira (Centro de Patologia Clínica Campana), Antonio Carlos Magnanelli (Fundação Pró-Sangue Hemocentro de São Paulo), Dr. Luiz Gastão Rosenfeld and Dr. Elena Alonso Quina (Hospital Israelita Albert Einstein), Dr. Magnólia Leão Nóbrega (FMUSP), Nestor Pinto Neto and Levi De Oliveira Jr. (Farma Service Indústria Farmacêutica Ltda), Dr. Maria Olímpia de Oliveira Rezende and Dr. Emanuel Carrilho (USP-São Carlos), Dr. Arnaldo Alves Cardoso (UNESP, Araraquara), Dr. Roy E. Bruns (UNICAMP), and Dr. Bronislaw Polakiewicz and Dr. Luíz Antonio Gioielli (FCF-USP).

\section{References}

1. Tavares, M. F. M.; Quim. Nova 1996, 19, 173.

2. Tavares, M. F. M.; Quim. Nova 1997, 20, 493. 
3. Landers, J. P. ed.; Handbook of Capillary Electrophoresis, CRC: New York, 1997.

4. Jager, A. V.; Tavares, M. F. M.; J. Chromatogr., B 2003, 785, 285.

5. Jager, A. V.; Tavares, M. F. M.; Electrophoresis 2003, 24, in print.

6. Colombara, R.; Tavares, M. F. M.; Massaro, S.; Quim. Nova 1997, 20, 512.

7. Jager, A. V.; Tavares, M. F. M.; Quim. Nova 2001, 24, 363.

8. Tagliaro, F.; Manetto, G.; Crivellente, F.; Scarcella, D.; Marigo, M.; Forensic Sci. Int. 1998, 92, 201.

9. Tomás-Barberán, F. A.; Phytochem. Anal. 1995, 6, 177.

10. Fonseca, F. N.; Kato, M. J.; Oliveira Jr., L.; Pinto Neto, N.; Tavares, M. F. M.; J. Microcolumn Sep. 2001, 13, 227.

11. Fujiya, N. M; Tavares, M. F. M.; J. Sep. Science 2003, 26, in print.

12. Colombara, R.; Tavares, M. F. M.; Massaro, S.; Anal. Chim. Acta 1999, 388, 171.
13. Souza, S. R;. Tavares, M. F. M.; Carvalho, L. R. F.; J. Chromatogr., A 1998, 796, 335.

14. Pereira, E. A.; Cardoso, A. A.; Tavares, M. F. M.; J. AOAC International, 1999, 82, 1562.

15. Pereira, E. A.; Carrilho, E.; Tavares, M. F. M.; J. Chromatogr. A 2002, 785, 285.

16. Pereira, E. A.; Cardoso, A. A.; Tavares, M. F. M.; Electrophoresis 2003, 24, 700.

17. Karcher, A.; El Rassi, Z; Electrophoresis 1997, 18, 1173.

18. Soga, T.; Serwe, M; Food Chem. 2000, 69, 339.

19. Oliveira, M. A. L.; Micke, G. A.; Bruns, R. E.; Tavares, M. F. M.; J. Chromatogr. A 2001, 924, 533.

20. Souza, M. V. N. de; Almeida, M. V. de; Quim. Nova 2003, 26, in print (scheduled for the may/june issue).

Received: October 19, 2002

Published on the web: April 9, 2003

FAPESP helped in meeting the publication costs of this article. 